\title{
Effect of Thinning on Pericopsis elata (Harms) Meeuwen (Fabaceae) Found in Forest Plantations in the East and South Regions of Cameroon
}

\author{
Jean Lagarde Betti ${ }^{1}$, Ferdinand Kemkeng ${ }^{1}$, Jules Romain Ngueguim $^{2}$, Joseph Ambara ${ }^{3} \&$ Maturin Tchatat ${ }^{4}$ \\ ${ }^{1}$ Department of Plant Biology, Faculty of Sciences, University of Douala, Cameroon \\ ${ }^{2}$ Institute for Agricutural Research and Development (IRAD), Yaoundé, Cameroon \\ ${ }^{3}$ Département de Foresterie, Faculté d'Agronomie et des Sciences Agricoles, Université de Dschang, Cameroon \\ ${ }^{4}$ Institute for Agricutural Research and Development (IRAD), Yaoundé, Cameroon \\ Correspondence: Jean Lagarde Betti, Department of Plant Biology, Faculty of Sciences, University of Douala, \\ BP 24157, Cameroon. Tel: 237-677-303-272. E-mail: lagardebetti@yahoo.fr
}

\author{
Received: May 17, 2020 Accepted: June 20, $2020 \quad$ Online Published: December 20, 2020 \\ doi:10.5539/jps.v10n1p1 URL: https://doi.org/10.5539/jps.v10n1p1
}

\begin{abstract}
This paper assesses the response of Pericopsis elata trees to silvicultural operations conducted in abandoned plantations settled between 1972 and 1975 in the East and South regions of Cameroon. Trees quality and DBH were evaluated before and 6 years after 2009 thinning. The silvicultural treatment of thinning improved the quality (physiognomy), the annual diameter increment and the stand basal area of trees. The average percentage of winding trees dropped from $82.8 \%$ in 2009 before thinning to $44.1 \%$, six years later after thinning (2015). The most important average diameters were observed in thinned plots $(27.3 \pm 10.4 \mathrm{~cm}-30.5 \pm 10.0 \mathrm{~cm})$ compared to non-thinned plots $(22.9 \pm 13.2 \mathrm{~cm}-23.3 \pm 10.8 \mathrm{~cm})$. Thinned plots gained at least $6 \mathrm{~cm}$ in diameter in 6 years, which is trice compared to the $2 \mathrm{~cm}$ observed in the non-thinned plots. The average annual diameter increment was $0.45 \mathrm{~cm} /$ year in thinned plots against $0.34 \mathrm{~cm} /$ year in non-thinned plots in the same period. Thinned plots have gain at least $6 \mathrm{~m}^{2} / \mathrm{ha}$ in the stand basal area against $1 \mathrm{~m}^{2} /$ ha for non-thinned plots.
\end{abstract}

Keywords: Pericopsis elata, CITES, thinning, annual diameter increment, structural maturity, forest plantations, Congo basin

\section{Introduction}

Cameroon is vast of 47.565 millions of hectares and is located in Central Africa. It is often considered as Africa in miniature due to the presence of various types of ecosystems and climates within its frontiers. The forest area of Cameroon covers 22 millions of hectares (MINFOF 2016).

Cameroon vegetation is composed of two main groups including the humid forests in the southern zone and the Sudanian and Sahelian savannah in the northern area. The zoning plan of the southern area (phases 1-4 of national inventory) led to division of the forest zone in two main domain types, namely the permanent domain (53.5\%) and the non-permanent domain (46.5\%). The non-permanent domain comprises the community forests, sales of standing volume (small forest concessions of not more than 2,500 ha), and mining zones. It is also composed of lands affected for agricultural and other agroforestry activities. The permanent domain is divided into the domanial or state forests which belong to the State, and communal forests which belong to the private domain of the council. The states forests are themselves divided into production forests, protected areas, and forest reserves. All state forests are supposed to be rigorously managed in the frame of management plans (République du Cameroun 1994, 1995).

When someone is talking about management plans in Cameroon, he/she? is thinking first to natural production forests composed mainly of forest management units (FMUs), and secondly to protected areas composed mainly of national parks and faunal reserves. Management plans of forest reserves or forest plantations are not accounted. No concrete effort has been made by the Cameroonian government regarding the elaboration and implementation of management plans of forest reserves/forest plantations.

In the framework of its reforestation and regeneration policy, the Cameroonian government has created many forest plantations in different agro-ecological zones. Within these plantations, silvicultural experiments on 
high-value timber species are being conducted. In total 35800 ha of forest plantations were installed in the country, distributed as follows: 4100 ha in dry savannah areas, 8700 ha in humid savannah areas, and 23000 ha in forest zone (MINEF 1995). For various reasons, these forestry plantations put in place were abandoned for over 30 years. All those plantations were settled without any management plan and many of them have been invaded by local populations.

Pericopsis elata (Harms) Meeuwen is a leguminous species of the Fabaceae family, normally known as Afrormosia or Assamela. Assamela wood can be substituted with Teck which has similar properties; this is why it is often referred to as African Teck. Pericopsis elata is a semi gregarious to gregarious tree and uses to grow on flat ground, valleys and slopes; its tree can reach a height of $20 \mathrm{~m}$ with a diameter of $130 \mathrm{~cm}$ measured from the breast level (dbh). The trunk is often twisted and irregular especially for the young trees. Trees attaining large diameters of more than $100 \mathrm{~cm}$ often have internal hollowed cavities or are corroded inside and often attacked by gummosis (Vivien and Faure 1985). The bark of $P$. elata is characterized by its brown color and red spots with a thickness of 1 to $1.5 \mathrm{~cm}$ for mature trees. $P$. elata trees flower annually or every two years during the short rainy season (March-April) and fructification occurs between May and December (Bourland 2013; Bourland et al. 2012, Nnanga et al, 2019).

P. elata is found in many areas in Central and West Africa precisely in Soudano-Zambezian areas in semi caducifolous forest (White 1983). In Cameroon, its natural habitat covers a surface area of 4071800 ha mainly concentrated in the south-east region of the country around the water basin of four rivers: Dja, Boumba, Ngoko, and Sangha. Despite this, some residual populations are found dispersed in the south region notably in the Dja and Lobo and the Ntem Divisions and also in the Manyu Division of the south west region (Vivien and Faure 1985).

In the Congo Basin, P. elata is a high-value furniture wood with excellent commercial potentials since it offers many technological options. It is used in, maritime constructions, flooring, veneer, furniture, and joinery. These different uses have contributed to its increasing demand in the wood market. P. elata is classified by the World Alliance for Nature (IUCN) as endangered species, which led to its listing in the Appendix II of the Convention on International Trade in Endangered Species of Fauna and Flora (CITES). As it is, the species is indeed endangered and has become all but locally extinct in some countries where the exploitation and international trade in this species had begun some 55 years ago. Significant stocks of the species still exist, however, in the Congo Basin, including Cameroon, Central African Republic (CAR), Democratic Republic of Congo (DRC), and Republic of Congo (Dickson et al. 2005).

P. elata constitutes part of the timber wood whose silviculture has been tested in Cameroon. This species was introduced in three forestry stations, namely Makak (Beng-Nyong), Kumba, Mbalmayo (Bilik) in the national school of Forestry (ENEF), in Ndeng ndeng forestry reserve (Ke' be' block) and in the Kienke south forestry reserve (Bidou II block) (Grison 1979; Engbwem 1988). These silvicultural plots had as objectives to search the best plantation density for this species. But it happened that the experiment sites were out of the natural milieu of this species and irregularity in the survey of the plantations hindered the collection of necessary data to explain the silviculture of this woody species. Some of the plantations like that of Bilik and Kumba did undergo illegal cutting and high land tenure pressure for urbanization and extension of farmer's fields. These external pressures have considerably reduced the total surface area planted initially estimated at 14 ha (Ngueguim et al. 2012).

The CITES Secretariat realized the challenges that range states of the CITES listing species face implementation of CITES requirements and it has teamed up with the International Tropical Timber Organization (ITTO) to help build capacities at the country level and promote the sustainable management of tropical forests including these species. This partnership in the frame of the so called "the ITTO-CITES program" has been strengthened considerably and funded national activities to assist non-detriment findings (NDFs) by developing forest inventories, management and silvicultural plans, setting up tracking systems, providing training, and developing training and working material. Since 2008, under the ITTO-CITES Program, ITTO has, in consultation with the CITES Secretariat, funded 25 Activities (projects) in Africa distributed as follows: Cameroon (9 activities), Congo-Brazzaville (5), Democratic Republic of Congo (5), Ghana (2) and four activities at regional level. When the program started in 2008, Pericopsis elata was included in the process of the significant trade review (STR), with the lack of NDFs and management plans being the core problem for range countries in the Congo Basin (CITES 2003; Dickson et al. 2005). The assistance of the ITTO-CITES Program to date in Cameroon on P. elata has focused on the development of non-detriment findings for natural stands and simple management plans and resource inventories for plantation forests. The activity, "management of Pericopsis elata in forest plantation in Cameroon" funded in the frame of this program allowed the National Forestry Development Agency (ANAFOR), the CITES Scientific authority of Cameroon, to dress and start implementing the first management plan of a 
forest plantation in Cameroon.

The management plan was dressed for the Bidou II forest plantation, located in the Kienké South forest reserve for a period of 10 years (2009-2019), to be reviewed at the fifth year. The document of the management plan declined five measures including: (1) the conservation of the Pericopsis wood through careful and selective thinning, (2) the production of seedlings for the creation of new forest plantations, (3) the improvement of the wellbeing of local populations, (4) the conservation of biodiversity of carbon storage, and (5) the realization of research (Tchatat 2009). The first measure implemented was the careful and selective thinning of trees, which occurred in end 2009. The Bidou II plantation was thinned in August-September 2009 as recommended in the simple management plan (ITTO-CITES program newsletter no 9, www.itto.int). Results related to the growth and productivity of these plantations before silvicultural interventions have already been published in 2012 (Ngueguim et al. 2012).

This paper aims to evaluate the response of Pericopsis elata trees upon the first selective thinning occurred in 2009. The specific objectives are (1) to assess the external quality or the physiognomy of trees (straightness and healthy), and (2) to analyse dendrometical parameters including diameter increment (growth rate), and stand basal area.

\section{Materials and Methods}

\subsection{Studied Sites}

The study was carried out in two forest reserves/forest plantations in Cameroon: Kienke south or Bidou II in the South region and Ndeng Ndeng in the East region.

\subsubsection{Plantation of the Ndeng Ndeng Forest Reserve}

Located at $4^{\circ} 30^{\prime}-5^{\circ} 30^{\prime}$ de Lat. North and at $13^{\circ} 11^{\circ}-13^{\circ} 30^{\prime}$ Long. East, the Ndeng Ndeng forestry reserve is situated in the Belabo subdivision, Lom and Djerem division, East region. According to Letouzey (1985), Ndeng Ndeng is found in the dense humid semi-deciduous forest rich in Sterculiaceae and Ulmaceae. The relief is relatively flat with weak slopes and its altitude varies between 600 and $750 \mathrm{~m}$. This reserve has three P. elata plots numbered P741, P745, and P746 with a total surface area of 5 ha. The letter P signifies parcel and the two first characters of each number refers to the year 1974 during which this plot was put in place by the Centre Technique Forestier Tropical, the institution that Cameroon confined forestry research to after 1960 . The third number $(1,5$, and 6$)$ indicates the rank of the plot. Average annual rainfall is $1500 \mathrm{~mm}$ with dry months in December, January, and February. The average annual temperature varies between 22 and $25.8^{\circ} \mathrm{C}$. The soils of this forestry ecosystem are lateritic. In the east the bedrock is made of mainly granite, in the west it is mainly metamorphic rocks, in the north it is mainly clayey-sandy whereas at the foot of slopes it is typically ferralitic hydromorphous soils (Etoga 1991).

\subsubsection{Plantation of Kienke South}

The Kienke South plantation is located at $2^{\circ} 48^{\prime}-2^{\circ} 55^{\prime}$ Lat. Nord and $10^{\circ} 00^{\prime}-10^{\circ} 17^{\prime}$ Long. East. Found in the south region, Kienke south is a forest reserve located in the Lokoundje Subdivision of the Ocean division, more precisely between the Kribi and Akom II sub-divisions. This reserve was classified in the state permanent domain as a forest production reserve by decision no. 393 of 8 November 1947. This forest reserve is linked to a plateau with an attitude between 100 and $200 \mathrm{~m}$ (ONADEF 1991). The Kienke south reserve has two P. elata plots numbered P73 and P75, with a total surface area of 0.7 ha. The first plot was planted in 1973 and the second one in 1975. The region has a Guinea equatorial climate, characterized by constant high temperatures. Highest rainfall is observed during the months of August and September. Annual precipitation varies between 1600 and $3300 \mathrm{~mm}$ and average monthly temperature is around $25.98{ }^{\circ} \mathrm{C}$ (Moby et al. 1979). Soils are young, ferralitic with a yellow color. The natural vegetation of the Littoral Atlantic forest is rich in Caesalpiniaceae, Saccoglottis gabonensis, and Lophira alata.

\subsection{Data Collection and Analysis}

\subsubsection{Description of the Planting Method Used}

The technique used for the installation of the plantations is the worn-out method. This consists of going into the forest and identifying big worn-out trees and destroying them to increase sunlight penetration and avoid competition for sunlight with the young plants to be put in place. The manager looks for a planting density which could help to obtain the best expression of the growth potentials of the tree. The planting densities were high in the Kienke south plots (P73 and P75) and low in the big corridors in the Ndeng ndeng plots (P745, P746) as shown in table 1. 
Table 1. The initial and 2009 density of the parcels before thinning

\begin{tabular}{|c|c|c|c|c|c|c|c|c|c|c|}
\hline Sites & $\begin{array}{l}\text { Planting } \\
\text { year }\end{array}$ & Parcels & $\begin{array}{l}\text { Initial } \\
\text { spacing } \\
\text { between } \\
\text { trees }(\mathrm{m})\end{array}$ & $\begin{array}{l}\text { Surface } \\
\text { area (ha) }\end{array}$ & $\begin{array}{l}\text { Initial } \\
\text { number } \\
\text { of trees } \\
\text { per parcel }\end{array}$ & $\begin{array}{l}\text { Initial } \\
\text { density of } \\
\text { trees (number } \\
\text { of trees/ha) }\end{array}$ & $\begin{array}{l}2009 \\
\text { Number of } \\
\text { trees } \\
\text { (trees/parcel) }\end{array}$ & $\begin{array}{l}2009 \\
\text { Density } \\
\text { of trees } \\
\text { (trees/ha) }\end{array}$ & $\begin{array}{l}2009 \\
\text { Survival } \\
\text { rate (\%) }\end{array}$ & $\begin{array}{l}\text { Number and } \\
\text { percentage } \\
\text { of infected } \\
\text { trees }\end{array}$ \\
\hline \multirow{2}{*}{$\begin{array}{l}\text { Kienke } \\
\text { south }\end{array}$} & 1973 & P73 & $3 \times 3$ & 0.38 & 424 & 1111 & 331 & 871 & 78 & $16(4.8 \%)$ \\
\hline & 1975 & P75 & $4 \times 3$ & 0.30 & 255 & 884 & 232 & 765 & 91 & $5(2.1 \%)$ \\
\hline \multirow{2}{*}{$\begin{array}{l}\text { Ndeng } \\
\text { ndeng }\end{array}$} & 1974 & P745 & $15 \times 3$ & 2 & 511 & 256 & 283 & 142 & 55,4 & $5(1.7 \%)$ \\
\hline & 1974 & P746 & $20 \times 3$ & 2 & 383 & 192 & 265 & 135 & 69 & $5(1.8 \%)$ \\
\hline
\end{tabular}

\subsubsection{Description of the Inventory}

Inventory was conducted in four plots including plots P73 and P75 in the Kienke south, and Plots P745 and P746 in Ndeng ndeng in two phases: phase I from $12^{\text {th }}$ April to $13^{\text {th }}$ June 2009 before the first thinning done in August-September 2009 and phase II, six years later from $3^{\text {rd }}$ January to $25^{\text {th }}$ March 2015 after. In each plot, all trees were systematically marked (numbered) on their eastern side, counted and their diameter measured at DBH level with a metric tape. The numbers attributed to each tree were noted for each stand tree as described by Ngueguim et al. (2012). The trees considered dead include the dead standing trees or falling trees. In this last case, during inventories in a plantation where the initial spacing is $3 \mathrm{~m} \mathrm{x} 3 \mathrm{~m}$, if for example the last marked stem carries the number " 03 " for instance and the next surviving stem is located at $12 \mathrm{~m}$ on the same line, we shall attribute the number "7". This indicates that the trees numbered 04, 05, and 06 are dead. For trees presenting bumps at DBH level, the diameter was measured at $30 \mathrm{~cm}$ above that level. For trees presenting two stems, the diameter was measured for each stem. For each tree, we noted the quality of stems as: straight, bump, or winding.

\subsubsection{Description of the Silvicultural Treatment}

A silvicultural treatment, consisting of thinning was conducted after each inventory campaign, by the National Forestry Agency (ANAFOR), the CITES Scientific authority for plants in Cameroon, within the ITTO-CITES program in 2009 and 2015 respectively. In fact, since the plantations have been settled (1973 - 1975), no appropriate silvicultural intervention was applied. In the beginning, the silvicultural experiments conducted aimed among other objectives, to test the best tree spacing that can yield better wood production. The high density observed in the settlement was supposed to be reduced progressively after years with the aim to reduce intra-specific competition for the light and improve the growth and the wood production. The first silvicultural treatment was supposed to occur when the crown of the trees was dense and started closing. For the Kienke south plantation for example, this was supposed to occur between 1980 and 1986, when the two plots had about 8 and 10-year-old respectively. But nothing was done. As a result, many trees were bump and winding.

In spite of the long delay observed, ANAFOR decided finally to elaborate the simple management plan of the Kienke south plantation with specific measures (Tchatat 2009). Because of the big delay observed, the document of the management plan suggested to make a prudent thinning with the aim to improve the wood production. In forestry, thinning is the selective removal of trees, primarily undertaken to improve the growth rate (diameter increment) or health of the remaining trees. The document suggested to make urgently two consecutive thinnings, the first scheduled in 2009 and the second in 2015. This should consist of cutting about 10-30\% of trees, focusing on trees which are dominated (low thinning), infested, or winding. Trees located on the border were left as to reduce the negative effect of winds. The first thinning was conducted in September 2009, cutting 23\% of trees in plot P73 and 16\% of trees in plot P75. The second thinning occurred in May 2015 which is six years after, cutting 15\% of trees in each of the two previous plots. A total of 30 trees were cut in P73 and 25 trees were cut in P75 (Kemkeng 2016).

\subsubsection{Estimating Structural Parameters}

A total of five structural parameters were estimated for each plot inventoried including: the density of trees, medium/average diameter, the mortality rate, the annual diameter increment, and the stand basal area.

Density of trees - as the report of the total number of trees with the total area of the plot. It is expressed in number of trees per hectare (ha).

The medium diameter - as the mean or the average diameter of all trees measured at DBH. 
The mortality rate - as the ratio in percent of the number of trees died naturally between the date of the last inventory and the current state of the plot.

The annual diameter increment (Di) - as the report of the average diameter (in $\mathrm{cm}$ ) of the population on the number of years (age) of the plot/plantation. It is expresses in $\mathrm{cm} /$ year.

The stand basal area - as the sum of the stand basal area of each tree within a hectare: $G=\pi / 4 \times \sum^{n} \mathrm{di}^{2}$

$\mathrm{G}$ is the stand basal area measured in $\mathrm{m}^{2} / \mathrm{ha}$ and di the diameter in $\mathrm{m}$.

The stand basal area increment (growth rate) or Gi, expresses in $\mathrm{m}^{2} / \mathrm{ha} / \mathrm{year}$, the report of the stand basal area (in $\mathrm{m}^{2} / \mathrm{ha}$ ) of the population on the number of years (age) of the plot/plantation.

\subsubsection{Statistical Analysis}

Data analysis was performed using the R version 3.5.1 (2018-07-02), Ri 386 computer packages. This bundleage served to make the one way ANOVA, for example to assess the variance of diameter, stand basal area, diameter increment or stand basal area increments between different populations including sites, parcels, parcel in a specific year.

\section{Results}

\subsection{Physionomy of Plantations and Diameter Structure of Plots in 2009}

Table 1 presents the initial and 2009 feature of the plots. The survival rates were acceptable in plots which had irregular surveys. The Ndeng ndeng plantations with big transects had average survival rates of less than $69 \%$ (P746) compared with those found in Bidou II where the higher survival rates are estimated at 91\% (P75). The quality of the survived trees noted in 2009 is presented in table 2. Many trees were bump and winding as showed. About an average of $85.2 \%$ of trees were winding, distributed as follow: Ndeng ndeng (87.8\%) and Kienke south $(82.8 \%)$.

Table 2. Quality of survived trees in Kienke south and Ndeng ndeng parcels in 2009 before thinning

\begin{tabular}{lllll}
\hline Sites & Parcel & Aspect of the stem & Number of trees & \% \\
\hline Kienke south & P73 & Bump & 26 & 7.8 \\
& & Bump and straight & 4 & 1.2 \\
& & Bump and winding & 39 & 11.8 \\
& & Straight & 33 & 10.0 \\
& & Winding & 229 & 69.2 \\
& P75 & Bump & 11 & 4.7 \\
& & Bump and straight & 1 & 0.4 \\
& & Bump and winding & 12 & 5.2 \\
& & Straight & 22 & 9.5 \\
Ndeng-ndeng & Winding & 186 & 80.2 \\
& & Bump & 3 & 1.1 \\
& & Bump and straight & 1 & 0.4 \\
& & Bump and winding & 33 & 11.6 \\
& & Straight & 27 & 9.5 \\
& Winding & 220 & 77.5 \\
& P746 & Bump & 9 & 3.4 \\
& & Bump and winding & 47 & 17.7 \\
& Straight & 27 & 10.2 \\
& Winding & 182 & 68.7 \\
\hline
\end{tabular}

The 2009 dendrometric characteristics of the parcels studied is presented in table 3. The most important average diameter is observed in plot P 73 with an average size of trees of $24 \pm 11 \mathrm{~cm}$. The standard deviations are high $(10-12 \mathrm{~cm})$. The average stand basal areas and annual diameter increment are high in the Kienke south compared to Ndeng ndeng.

Till 2009 which was 34 or 36 years after for the Kienke south parcels, no silvicultural treatment was made in spite of the development delay and the bad conformity of trees as shown in Figure 1. 
Table 3. The characteristics of the studied population in 2009 , before thinning

\begin{tabular}{llllllllll}
\hline & Parcels & $\begin{array}{l}\text { Surface } \\
\text { Area } \\
\text { (ha) }\end{array}$ & Age & $\begin{array}{l}\text { Density } \\
\text { (trees/ha) }\end{array}$ & $\begin{array}{l}\text { Stand basal } \\
\text { area or } \\
\mathrm{G}\left(\mathrm{m}^{2} / \mathrm{ha}\right)\end{array}$ & $\begin{array}{l}\text { Mean diameter } \\
\text { or Dm }(\mathrm{x} \pm \mathrm{SD} \\
\text { in } \mathrm{cm})\end{array}$ & $\begin{array}{l}\mathrm{G} \text { increment or } \\
\mathrm{Gi}(\mathrm{m} / \mathrm{ha} / \mathrm{year})\end{array}$ & $\begin{array}{l}\text { Annual diameter } \\
\text { increment or } \\
\text { Di (cm/year) }\end{array}$ & $\begin{array}{l}\text { Revolution } \\
\text { years }\end{array}$ \\
\hline Kienke south & P73 & 0.38 & 36 & 871 & 46.25 & $24 \pm 11$ & 1.28 & 0.67 & 149 \\
& P75 & 0.30 & 34 & 765 & 32.78 & $21 \pm 10$ & 0.96 & 0.62 & 161 \\
Ndeng ndeng & P745 & 2 & 35 & 142 & 6.34 & $21 \pm 12$ & 0.18 & 0.60 & 167 \\
& P746 & 2 & 35 & 135 & 5.33 & $21 \pm 10$ & 0.15 & 0.60 & 167 \\
\hline
\end{tabular}

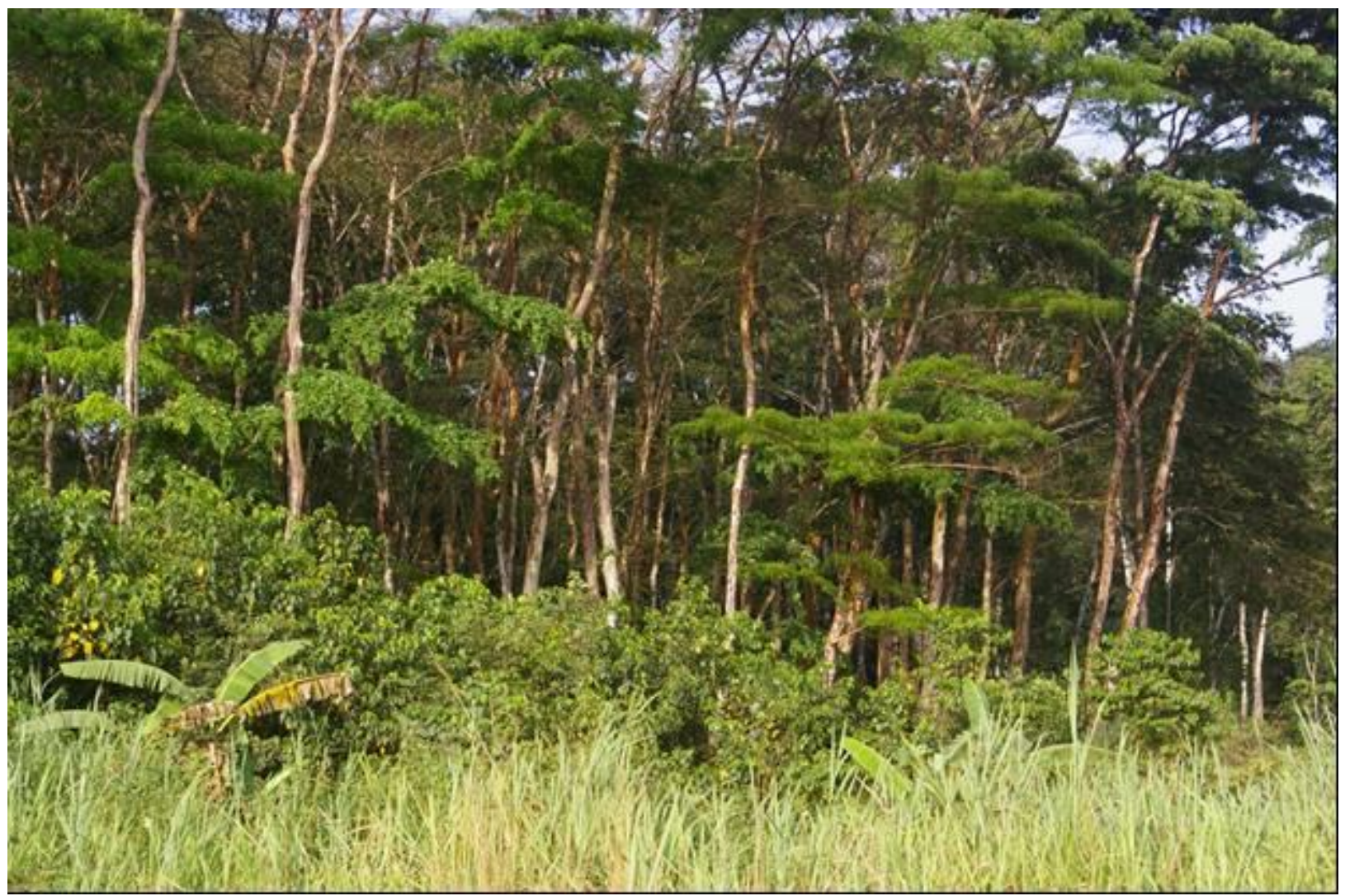

Figure 1. Betti Jean Lagarde. Physionomy of the Kienke south plantation in 2009. Photo Betti, Bidou II, Kribi, Cameroon, March 2009

Figure 1 illustrates the diameter structures of Pericopsis elata plots in 2009. Higher diameter classes contain fewer trees. The modal class is Cl10-20 in all plots. Because of the big delay observed, the document of the management plan of the Kienke south suggested to start with a selective and careful thinning of trees and the reduction of the plantation density. The most suitable approach will necessitate: Thinning that eliminates very few stems especially in areas that can be fragile, avoid thinning the two first hedges of trees of each plot, they will serve as wind protection residues; a top thinning is good for dominant stems to provide a favorable interval for diameter growth for these stems by progressive and partial removal of dominant; regarding infested trees, remove only those that are seriously affected to avoid the risk of withering due to a high rate of thinning; eliminate trees with poor performance. Figure 2 illustrates the 2009 physionomy of the thinned plots in the Kienke south forest reserve. 


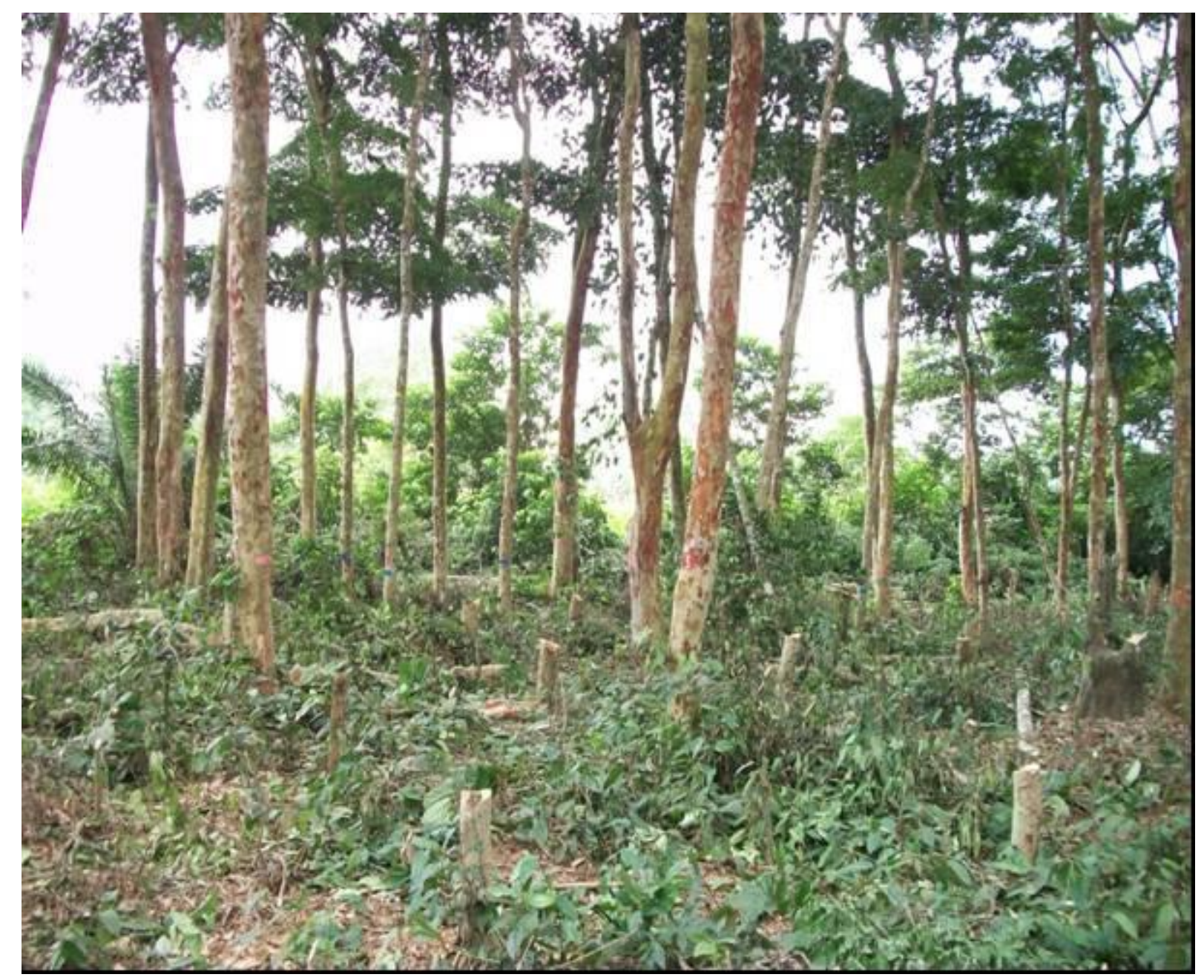

Figure 2. Ngueguim Jules_Physionomy of the Kienke south plantation in November 2010. Bidou II, Kribi, Cameroon, November 2010

\subsection{Physionomy of Plantations and Diameter Structure of Plots in 2015}

Table 4 presents the quality of the remaining trees upon thinning in the Kienke south site in 2015. The average percentage of winding trees is $44.1 \%$.

Table 4. Quality of survived trees in Kienke south after thinning in 2015

\begin{tabular}{llcc}
\hline Parcel & Aspect of the tree & Number of trees & $\%$ \\
\hline P73 & Straight & 111 & 50.7 \\
& Winding & 52 & 23.7 \\
& Bump and winding & 56 & 25.6 \\
P75 & Straight & 96 & 61.1 \\
& Winding & 23 & 14.6 \\
& Bump and winding & 38 & 24.2 \\
Total & & 376 & 100 \\
\hline
\end{tabular}

Table 5 presents the dendrometric characteristics of the studied plots in 2015. Densities in plots of Kienké south have been largely reduced. The highest stand basal areas and diameter increments are found in thinned plots, Kienké south. The diameter increment increased by $110 \%$ in thinned plots, passing from $0.67-0.74 \mathrm{~cm} /$ year in P73 and from 0.62-0.68 cm/year in P75. In contrary, that parameter decreased in non-thinned plots by $93 \%$, passing from $0.60-0.56 \mathrm{~cm} / \mathrm{year}$ in P745 and P746. 
Table 5. The dendrometric characteristics of the studied population in 2015

\begin{tabular}{|c|c|c|c|c|c|c|c|c|}
\hline Sites & Parcels & Age & $\begin{array}{l}\text { Number } \\
\text { of trees } \\
\text { (per parcel?) }\end{array}$ & $\begin{array}{l}\text { Density } \\
\text { (Trees/ha) }\end{array}$ & $\begin{array}{l}\text { Stand basal } \\
\text { area }(\mathrm{G}) \\
\left(\mathrm{m}^{2} / \mathrm{ha}\right)\end{array}$ & $\begin{array}{l}\mathrm{G} \text { increment } \\
\text { or } \mathrm{Gi} \\
\left(\mathrm{m}^{2} / \mathrm{ha} / \text { year }\right)\end{array}$ & $\begin{array}{l}\text { Mean diameter } \\
\text { or } \mathrm{Dm}(\mathrm{x} \pm \mathrm{SD} \\
\text { in } \mathrm{cm})\end{array}$ & $\begin{array}{l}\text { Annual diameter } \\
\text { increment } \\
\text { or Di (cm/year) }\end{array}$ \\
\hline \multirow[t]{2}{*}{ Kienke south } & P73 & 42 & 191 & 499 & 44.07 & 1.05 & $31 \pm 10.04$ & 0.74 \\
\hline & P75 & 40 & 139 & 454 & 31.32 & 0.78 & $27 \pm 10.47$ & 0.68 \\
\hline \multirow[t]{2}{*}{ Ndeng ndeng } & P745 & 41 & 261 & 130 & 7.31 & 0.18 & $23 \pm 13.11$ & 0.56 \\
\hline & P746 & 41 & 252 & 126 & 6.50 & 0.16 & $23 \pm 10.91$ & 0.56 \\
\hline
\end{tabular}

The diameter structure of Pericopsis elata plots in 2015 is illustrated in figure 4. The modal class of Cl10_20 remains the same for Ndeng ndeng plots. The new modal class of Kienke south plots is Cl20_30.

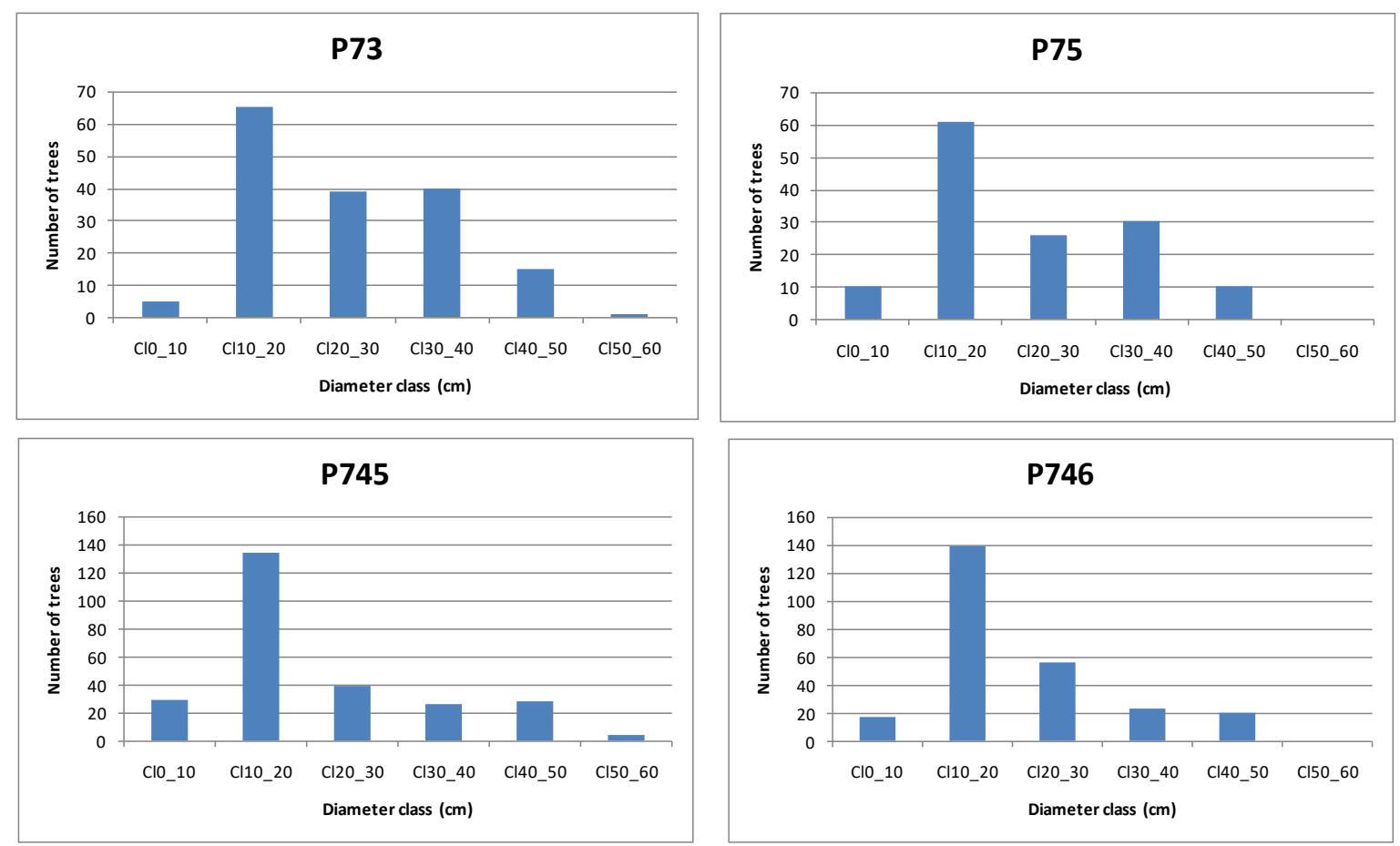

Figure 3. Diameter structure of Pericopsis elata in 2009 in Kienke south (P73, P 75) and Ndeng ndeng (P745, P746) forest reserve
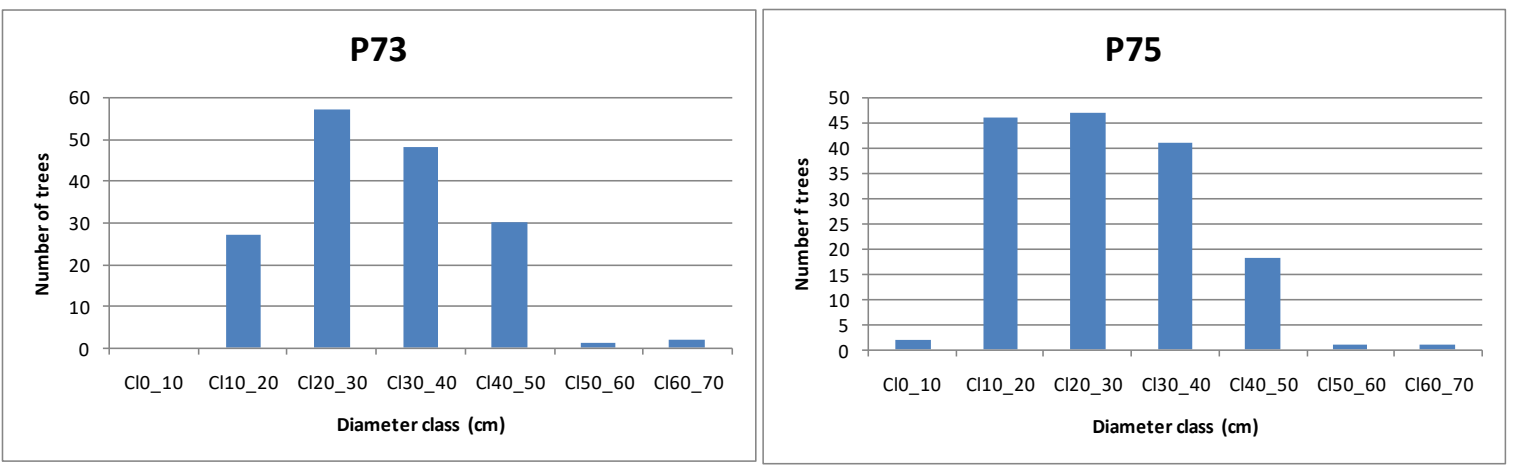

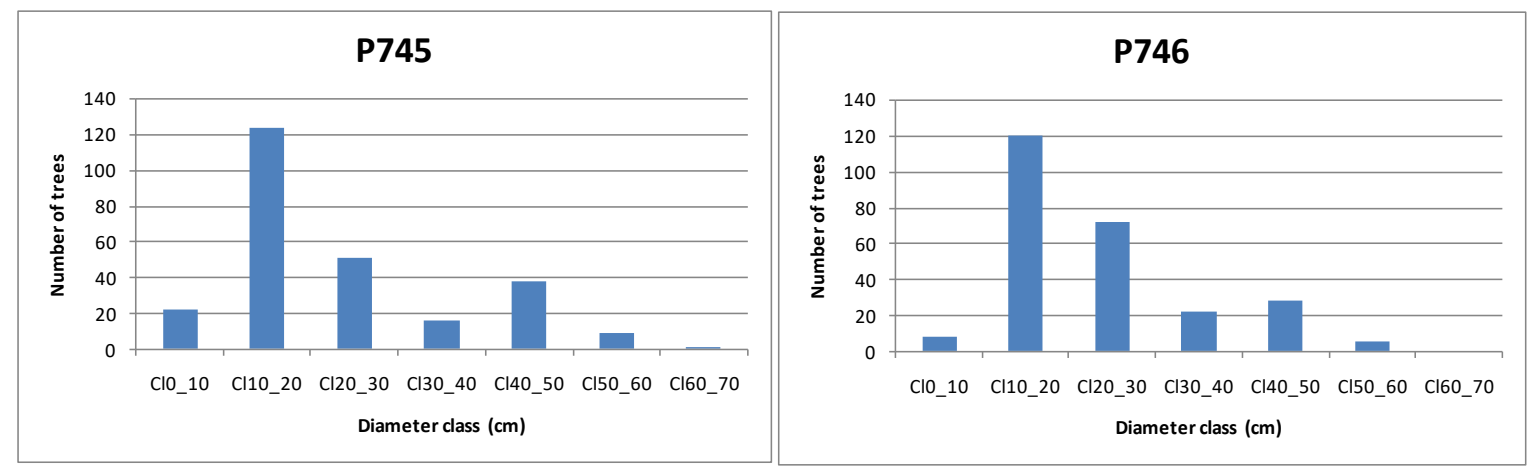

Figure 4. Diameter structure of Pericopsis elata in 2015 in Kienke south (P73, P 75) and Ndeng ndeng (P745,

P746) forest reserve

\subsection{Change on Dendrometric Characteristics between 2009 and 2015}

To understand the effect of thinning on the trees, we examined the change occurred between 2009 and 2015, which is 6 years after the thinning and for the same trees. Changes obtained on the stand basal area were examined between the two sites and inside each site as shown in table 6 . We can see that changes in stand basal area are significantly different between the two sites. But change inside each site is not different. The gain in stand basal area seems to be the same in the parcels belonging to the same site.

Table 6. Comparison of sites and parcels on changes in stand basal areas

\begin{tabular}{llllll}
\hline Site & $\begin{array}{l}\text { Number } \\
\text { of trees (N1) }\end{array}$ & $\begin{array}{l}\text { Number of } \\
\text { trees (N2) }\end{array}$ & $\begin{array}{l}\text { Stand basal } \\
\text { area (Mean 1) }\end{array}$ & $\begin{array}{l}\text { Stand basal } \\
\text { area (Mean 2) }\end{array}$ & Significance \\
\hline Kienke south x Ndeng ndeng & 331 & 521 & 0.037 & 0.004 & $\mathrm{~F}=287.2 ; \mathrm{P}=2 \mathrm{e}-16$ *** \\
Kienke south '(P73 x P75) & 192 & 139 & 0.035 & 0.039 & $0.421 \mathrm{Ns}$ \\
Ndeng ndeng (P745 x P746) & 270 & 251 & 0.004 & 0.004 & $0.057 \mathrm{Ns}$ \\
\hline
\end{tabular}

The $\mathrm{F}$ value and $\mathrm{P}$ are from the comparison between different sites and parcels. Signif. codes: 0 '***' $0.001{ }^{\prime * * \prime}$ 0.01 '*' 0.05 '.' 0.1 ' ' 1 , Ns: non significatif

Table 7 presents the mean difference of the stand basal area in each plot, while Table 8 compares the stand basal area increments of the same plots for 2009 and 2015. We can see that the Kienke south plots have gain more stand basal areas, about 10 times more than the Ndeng ndeng plots in 6 years. But there is no significance differences observed in term of stand basal area increments for the same plots.

Table 7. Changes on the stand basal area between 2009 and 2015 on the same trees

\begin{tabular}{lllllll}
\hline Site & Parcel & Age & $\begin{array}{l}\text { Number } \\
\text { of trees }\end{array}$ & $\begin{array}{l}\text { Stand basal area } \\
\text { in 2009 after } \\
\text { thinning }\left(\mathrm{m}^{2} / \mathrm{ha}\right)\end{array}$ & $\begin{array}{l}\text { Stand basal } \\
\text { area in } 2015 \\
\left(\mathrm{~m}^{2} / \mathrm{ha}\right)\end{array}$ & $\begin{array}{l}\text { Mean difference } \\
\text { in stand basal } \\
\text { area }(\mathrm{m} / \mathrm{ha})\end{array}$ \\
\hline Kienke south & P73 & 6 & 192 & 35.06 & 41.81 & $0.035 \pm 0.048$ \\
& P75 & 6 & 139 & 22.24 & 29.93 & $0.039 \pm 0.034$ \\
Ndeng ndeng & P745 & 6 & 270 & 6.15 & 7.24 & $0.004 \pm 0.005$ \\
& P746 & 6 & 251 & 5.32 & 6.49 & $0.005 \pm 0.005$ \\
\hline
\end{tabular}


Table 8. Comparison of plots on change in Stand basal area increments

\begin{tabular}{lllllll}
\hline Site & $\begin{array}{l}\text { Number of } \\
\text { trees 2009 } \\
(\mathrm{N} 1)\end{array}$ & $\begin{array}{l}\text { Number of } \\
\text { trees 2015 } \\
(\mathrm{N} 2)\end{array}$ & $\begin{array}{l}\text { G increment } \\
\text { Mean 2009 } \\
\left(\mathrm{m}^{2} / \mathrm{ha} / \text { year }\right)\end{array}$ & $\begin{array}{l}\text { G increment } \\
\text { Mean 2015 } \\
\left(\mathrm{m}^{2} / \mathrm{ha} / \text { year }\right)\end{array}$ & Sf & \\
\hline Kienke south '(P75 x P75) & 155 & 155 & 0.0056 & 0.0053 & 1 & $0.50 \mathrm{Ns}$ \\
Ndeng ndeng '(P745 x P745) & 271 & 275 & 0.0068 & 0.0068 & 1 & $0.88 \mathrm{Ns}$ \\
Ndeng ndeng (P746 x P746) & 255 & 258 & 0.0061 & 0.0064 & 1 & $0.59 \mathrm{Ns}$ \\
\hline
\end{tabular}

The $\mathrm{F}$ value and $\mathrm{P}$ are from the comparison between different sites and parcels. Signif. codes: 0 '***' $0.0011^{\prime * *}$ 0.01 '*' 0.05 '.' 0.1 ' ' 1 , Ns: non significatif

Table 9 and 10 present change occurred in annual diameter increment between 2009 and 2015 for the same trees. Changes in annual diameter increment differ from one site to another, and for the Ndeng ndeng site, from one parcel to another.

Table 10 presents the changes on annual diameter increment. The annual diameter increments in Kienke south plots are higher, than those in the Ndeng ndeng.

Table 9. Comparison of sites and plots on change in diameter increments

\begin{tabular}{llllll}
\hline Site & $\begin{array}{l}\text { Number of trees } \\
(\mathrm{N} 1)\end{array}$ & $\begin{array}{l}\text { Number of trees } \\
(\mathrm{N} 2)\end{array}$ & $\begin{array}{l}\text { Di Mean } 1 \\
(\mathrm{~cm} / \text { year })\end{array}$ & $\begin{array}{l}\text { Di Mean } 2 \\
(\mathrm{~cm} / \text { year })\end{array}$ & Significance \\
\hline Kienke south x Ndeng ndeng & 331 & 521 & 0.45 & 0.34 & $\mathrm{~F}=15.83 ; \mathrm{p}=7.52 \mathrm{e}-05 * * *$ \\
Kienke south (P73 x P75) & 192 & 139 & 0.46 & 0.45 & $0.832 \mathrm{Ns}$ \\
Ndeng ndeng (P745 x P746) & 270 & 251 & 0.3 & 0.4 & $\mathrm{~F}=23.15 ; \mathrm{P}=1.96 \mathrm{e}-06 * * *$ \\
\hline
\end{tabular}

The $\mathrm{F}$ value and $\mathrm{P}$ are from the comparison between different sites and parcels. Signif. codes: $0{ }^{\prime * * * \prime} 0.001$ ' $* *$ ' 0.01 '*' 0.05 '.' 0.1 ' ' 1 , Ns: non significatif

Table 10. Changes on the diameter increments between 2009 and 2015 on the same trees

\begin{tabular}{|c|c|c|c|c|c|c|c|c|c|}
\hline Site & $\begin{array}{l}\text { Planting } \\
\text { year }\end{array}$ & Parcel & $\begin{array}{l}\text { Initial spacing } \\
\text { between trees }(\mathrm{m})\end{array}$ & Age & $\begin{array}{l}\text { Number } \\
\text { of trees }\end{array}$ & $\begin{array}{l}\text { Mean } \\
\text { diameter } \\
2009(\mathrm{~cm})\end{array}$ & $\begin{array}{l}\text { Mean } \\
\text { diameter } \\
2015(\mathrm{~cm})\end{array}$ & $\begin{array}{l}\text { Mean difference } \\
\text { in diameter }(\mathrm{cm})\end{array}$ & $\begin{array}{l}\text { Di } \\
\text { (cm/year) }\end{array}$ \\
\hline \multirow[t]{2}{*}{ Kienke south } & 1973 & P73 & $3 \times 3$ & 6 & 192 & 28 & 31 & $2.6 \pm 3.4$ & 0.46 \\
\hline & 1975 & P75 & $4 \times 3$ & 6 & 139 & 24 & 27 & $2.8 \pm 3.13$ & 0.45 \\
\hline \multirow[t]{2}{*}{ Ndeng ndeng } & 1974 & P745 & $15 \times 3$ & 6 & 261 & 21 & 23 & $1.79 \pm 1.49$ & 0.3 \\
\hline & 1974 & P746 & $20 \times 3$ & 6 & 252 & 21 & 23 & $2.41 \pm 1.74$ & 0.4 \\
\hline
\end{tabular}

\section{Discussion}

\subsection{Physionomy, Dendrometric Characteristics and Diameter Structure of Plantations in 2009 before the First Thinning Campaign}

The two plantations including Kienke south and Ndeng ndeng, differ on the silvicultural method used. Planting densities were high in the Kienke south plots (P73, and P75) and low in the big corridors plots in Ndeng ndeng (P745, P746). The survival rates are high in Kienke south plots and low in Ndeng ndeng. But these survival rates are acceptable for plantations which were abandoned for many years. Tree mortalities were due less to human pressure than to natural death related to climatic and edaphic factors. As noted by Ngueguim et al. (2012), many falling trees were observed in plots with big corridors due to strong winds.

Density is an important parameter for the success of a plantation. During the creation of plantations, densities were projected to be reduced progressively with the aim to reduce shading. But this did not happened. As shown in Figure 1, the tree canopies inter-cross in the Kienke south plantations, showing a high competition for light due to high tree density. Many trees were bump and winding. An average of $85.2 \%$ of the survived trees were winding. The stems have a twisted and cylindrical trunk which is a characteristic of Pericopsis elata (Assamela/Afrormosia). Natural thinning occurs very well in all the plantations due to the reduced number of trees with low branching. Parasite infestation especially by black nut fungus was observed in all the plantations.

The most important average diameter is observed in plot $P 73$ with an average size of trees of $24 \pm 11 \mathrm{~cm}$. The relative high standard deviation indicates a high variability in the performance of the diameter growth of the 
trees. In fact, we noted that trees settled in the boundaries of each plot were quite big compared to those settled inside the plot. This illustrates competition between individual and predicts that a better follow-up and earlier intervention to reduce shade would have improved the yield (Ngueguim et al., 2012). The average stand basal areas and annual diameter increment are high in the Kienke south compared to Ndeng ndeng. This may be linked to the high densities of trees practiced in the Kienke south forest reserve.

Studies on the growth of Assamela indicate annual diameter increment of $3 \mathrm{~cm} /$ year for 8 -year-old plantations (FAO, 2008). In the Democratic Republic of Congo (DRC), Donis (1986) obtained $0.39 \mathrm{~cm} /$ year in 13 year-old plantations after 13 years of monitoring. In Ghana, Anglaaere (2005) obtained $1.3 \mathrm{~cm} /$ year on 7 year old plantations. In Cameroon, in the Kienke south forest reserve, results were $1 \mathrm{~cm} /$ year when the parcels were 12-year-old (Engbwem 1988) and $0.75 \mathrm{~cm} /$ year when they reached 32-year-old (Ngueguim 2007). In the Ndeng ndeng forest reserve, Grison (1979) noted for 5-year-old plantation, $1.16 \mathrm{~cm} / \mathrm{year}$ for parcel P745 and 1.32 $\mathrm{cm} /$ year for parcel P746. Results of the current study are as follow: $0.62 \mathrm{~cm} /$ year in 34-year-old plot (P75), 0.67 $\mathrm{cm} /$ year in 36-year-old plot (P73) and $0.60 \mathrm{~cm} /$ year in 35-year-old plots (P745 and P746). These annual diameter increments are low compared to results obtained in past years in the same plots. The drop in annual diameter increment can be explained by the negative effect of the absence of silvicultural treatment on mortality (diminution of the diameter size), competition between trees due to high planting densities and probably also by the normal growth rate which is a function of age. Results obtained in different studies conducted in range countries (Cameroon, DRC, Ghana) tend to show that the annual diameter increment varies not only with the age of plantation (young plantations seem to have high growth rates), but also with other parameters such as the site, the planting method, and probably the silvicultural treatment.

The most important annual diameter increment is $0.67 \mathrm{~cm}$ (P73) corresponding to a revolution of 149 years. This is the duration for the majority of trees in the plantation to reach the minimum cutting diameter allowed in Cameroon which has been increased from $90 \mathrm{~cm}$ in 2009 to $100 \mathrm{~cm}$ in 2010 for Pericopsis elata (Akoa et al. 2009). Stems with diameters higher or nearer the minimum cutting diameter of $100 \mathrm{~cm}$ were noticed generally located at the boundaries of the plots illustrating the border effect. Ngueguim et al. (2012) noted that, if a thinning intervention was done earlier, it would have reduced the population density and without doubt improved the diameter growth of the trees.

The most important stand basal areas observed are $46.25 \mathrm{~m}^{2} / \mathrm{ha}(\mathrm{P} 73)$ and $32.78 \mathrm{~m}^{2} / \mathrm{ha}$ (P75) and the lower are $6.34 \mathrm{~m}^{2} / \mathrm{ha}(\mathrm{P} 745)$ and $5.33 \mathrm{~m}^{2} / \mathrm{ha}(\mathrm{P} 746)$. This parameter depends on tree density and size. The curve of the diameter structures indicates that higher diameter classes contain fewer trees. The modal class is class 10-20 in all plantations and all plots. The structure of the population distribution is generally asymmetric to the right. Histograms are characterized by a very strong slope before the modal class of stems. This sudden and sharp elevation of number of stems after the diameter class of $\mathrm{dbh} 10 \mathrm{~cm}$ showed that the first diameter class is made up of stems which had problems of growth. This variability in diameter distribution demonstrates not only the specific character of silvicultural methods on each plantation but also the huge disparity of the diameters around the mean. In silvicultural systems in which stands have an even-aged structure, it was expected that the diameter of trees should be distributed to give a graphical representation of a bellshaped curve (Gaussian distribution) where the top represents the average tree. Generally, these plantations don't reflect the expected characteristics notable in those of an evenaged plantation structure. This confirms irregularity in the survey, absences of silvicultural interventions to accompany the tree growth process, the establishment of the trees out of their ecological zone, and the presence of other forms of perturbations due to abandonment (Ngueguim et al. 2012).

\subsection{Physionomy, Dendrometric Characteristics and Diameter Structure of Plantations in 2015}

The silvicultural intervention occurred in the Kienke south plots in 2009, while the plantations of the Ndeng ndeng forest were kept intact. We can note that the quality of trees has improved in the Kienke south plots. The average percentage of winding trees dropped from $82.8 \%$ in 2009 to $44.1 \%$ in 2015 , which is the half. Knowing that the silvicultural intervention moved an average of $19 \%$ of trees in the two plots, we can say that the quality of the survived trees has significantly improved. Similar results have been obtained by Drapeau (2005) in Canada.

The most important average diameters are observed in the Kienke south plantation, plot P 73 with an average size of $31 \pm 10.04 \mathrm{~cm}$ followed by plot 75 with an average size of trees of $27 \pm 10.47 \mathrm{~cm}$. The two plots gained at least $6 \mathrm{~cm}$ in diameter in 6 years, which is trice compared to the $2 \mathrm{~cm}$ observed in the Ndeng ndeng plantation. The evolution of the diameter increment is going to the same sense as the average diameter size. The highest diameter increments were observed in the Kienke south plots, $0.74 \mathrm{~cm} / \mathrm{year}$ in P73 and $0.68 \mathrm{~cm} / \mathrm{year}$ in P75. The P73 diameter increment moved from $0.67 \mathrm{~cm} /$ year in 2009 to $0.74 \mathrm{~cm} /$ year in 2015, while that of the P75 moved 
from $0.62 \mathrm{~cm} /$ year in 2009 to $0.68 \mathrm{~cm} /$ year in 2015 . The gain in diameter increment is about $0.065 \mathrm{~cm}$ in the two plots. The Ndeng ndeng plantation in the other hand registered a decrease in annual diameter increments, which dropped from $0.60 \mathrm{~cm} /$ year to $0.56 \mathrm{~cm} /$ year in the two plots (P745 and P746). The increase in average diameter size and annual diameter increments in the Kienke south plots can certainly be translated by the removal of small trees, since the thinning focused on dominated (thinning by the low) and winding trees. But the real reason can be the growth and development induced by the thinning. This result tends to confirm that, the thinning accelerates the structural maturity of the trees (Jeong-Seok Kang,Masato Shibuya and Chang-Seob Shin 2014 ; Drapeau 2005; Guitet et al. 2009). This acceleration is more important in P73, thinned at 23\% compared to P75 thinned at 16\%. When assessing the results of the forest tending project in Pinus koraiensis plantations in the South Korea, Jeong-Seok Kang,Masato Shibuya and Chang-Seob Shin (2014) noted that, with the thinning rates (intensity) high than $30 \%$, the annual diameter growth rate of pine trees increased apparently in the next year of thinning, and the increased growth continued for some years. They therefore concluded that the forest-tending (i.e. thinning) in plantations of Pinus koraiensis effectively enhanced tree growth. However, the increased growth continued only for 5 years in plantations thinned, and a clear trend between thinning rate and the increase in annual diameter growth rate was not found. Drapeau (2005) observed for the grey pin (Pinus banksiana) in Canada that, thinning intensity of less than $15 \%$ does not significantly induce changes in diameter structure maturity. She noted that, the more the plots are thinned, the more the structural maturity of trees increases. While testing different selective thinning methods in tropical forests in the French Guiana, Guitet et al. (2009) observed that diameter increment or the structural maturity of trees is significantly correlated to the thinning intensities less than 25\%. Our experiment used thinning intensities of 23\% and 16\% respectively in P73 and P75, which are in the limits suggested by the precited authors, and which can explain the high annual diameter increments obtained in this study.

Contrary to the diameter size, the stand basal area dropped a little bit in the Kienke south plots $\left(46-44 \mathrm{~m}^{2} / \mathrm{ha}\right.$ in P73 for example) and increased in the Ndeng ndeng plots (6-7 $\mathrm{m}^{2} / \mathrm{ha}$ in P745). There is no significance differences observed in term of stand basal area increments for the same plots. These results can be explained by the thinning operation which moved some trees and reduced the density. The stand basal area being largely linked to the density of trees, than to the size. Similar results have been obtained by several authors (Drapeau 2005; Guitet et al. 2009). Guitet et al. (2009) noted that thinnings induce only a little gain in terms of stand basal area. The curves illustrating the diameter structure have changed in the Kienke south plots, where the modal class has moved from $10-20 \mathrm{~cm}$ to $20-30 \mathrm{~cm}$. This reflects the increase observed in diameter size. Till here, no concrete element has translated the positive or negative effect of the silvicultural treatment operated.

\subsection{Change on Dendrometric Characteristics between 2009 and 2015}

In forests managed for timber production, thinning is probably the most important operation carried out between canopy closure and the final harvest. By removing the smaller, weaker and poorer quality trees growth is concentrated on the better trees remaining (Stoneman et al. 1996 cit. Drapeau 2005). To understand the effect of the thinning on the trees, we examined the change occurred between the 2009 and 2015, which is 6 years after the treatment and for the same trees. Change was examined between the two sites and inside each site. Change in stand basal area is significantly different between the two sites. But change inside each site is not different. The gain in stand basal area seems to be the same in the parcels belonging to the same site. Parcels of the Kienke south have gain at least $6 \mathrm{~m}^{2} / \mathrm{ha}$ in the stand basal area against only $1 \mathrm{~m}^{2} / \mathrm{ha}$ for parcels of the Ndeng ndeng during the 6 years. This illustrates the positive effect of the thinning on the development of Pericopsis elata. Changes in diameter growth and annual diameter increments are significantly different between the two sites. The annual diameter increments is the same in the Parcels of the Kienke south site $(0.45-0.46 \mathrm{~cm} / \mathrm{year})$, but differ between the two plots of the Ndeng ndeng site. The average annual diameter increments is $0.45 \mathrm{~cm} / \mathrm{year}$ in thinned plots (Kienke south) against $0.34 \mathrm{~cm} /$ year in non-thinned plots (Ndeng ndeng), which show again the positive effect of the thinning on the development of the trees. Similar results have been noted in other studies (Drapeau 2005; Guitet et al. 2009; Jeong-Seok Kang,Masato Shibuya and Chang-Seob Shin 2014; Breda et al. 1995). New environmental conditions observed in thinned plots can easily explain those increasements. Thinning induces the reduction of the leaf area, by moving some trees. Then, trees respond by increasing their leaf biomass and their production capacity per leaf unit of the remaining trees. Those two responses can be caused by an increase in the light quantity, a reduction of average temperatures, and a reduction of the length and severity of periods of water/humidity stress (Baldwin et al. 2000 ; Pouderoux et al. 2001 ; Harrington et Edwards 1999; Stoneman et al. 1996 ; 1999 cit. Drapeau 2005). Breda et al. (1995) conducted a thinning experiment in a 43-year-old Quercus petraea stand and noted that, predawn leaf water potential was significantly higher in trees in the thinned stand than in the closed stand, as a consequence of higher relative extractable water in the soil. The 
improvement in water availability in the thinned stand resulted from decreases in both interception and transpiration. Thinning increase inter-tree variability in sap flow density, which is closely related to a leaf area competition index.

Our results on diameter increment are quite similar to those obtained in natural forests in Cameroon and Democratic Republic of Congo (DRC). The $0.31 \mathrm{~cm} /$ year obtained in the non-thinned plots (Ndeng ndeng) is near the $0.31 \mathrm{~cm} /$ year obtained by Bourland (2013) on 51 trees monitored in natural forests in the East region of Cameroon. The $0.45 \mathrm{~cm} /$ year obtained in the cleaned plots is quite similar to those obtained by Vangu-Lutete (1974) and Boyemba (2011) in the Kisangani forest in DRC. In fact, Vangu-Lutete (opcit.) obtained $0.45 \mathrm{~cm} /$ year on 101 trees, while Boyemba (2011) obtained $0.42 \mathrm{~cm} /$ year on 422 trees using the same method. Schmitz (1962) followed 11 trees in Kisangani and obtained an annual growth rate of $0.68 \mathrm{~cm} /$ year. Annual growth rate depends of many environmental parameters including soils, climate, and the history of the forest in terms of the past usage. The difference observed between the work of Bourland (2013) in Cameroon and those conducted in DRC (Vangu-Lutete 1974; Boyemba 2011) can be translated by this thesis, and also may be by the low number of trees monitored in Cameroon. By comparing our results with those obtained in natural forests in DRC, we can see that, in spite of the delay, the silvicultural intervention has increased the growth rate and allowed the thinned plots to meet the normal annual growth rates of Pericopsis elata often observed in natural forests. The second thinning occurred in May 2015, retrieving 15\% of trees in each of the two previous plots. The next campaign of forest inventory should be scheduled by 2021, as to re-examine the effect of this second thinning on the health and growth of Pericopsis trees.

The annual diameter increment is one of the most important parameter that intervenes in the formula of the estimation of the reconstitution/recovery rate of Pericopsis elata in the production forests (forest management units) in the tree most range countries in the Congo basin including Cameroon, Republic of Congo, and DRC. In Cameroon (Akoa et al. 2009) and Republic of Congo (Nzala et al. 2011), the respective forest administrations have fixed the value of $0.4 \mathrm{~cm} /$ year as standard, to be used in the calculation of the reconstitution rate in all forest management units settled in the range area of Pericopsis elata (East Cameroon and North Congo), while in DRC (ICCN 2014), the forest administration has adopted a value of $0.45 \mathrm{~cm} / \mathrm{year}$ in Equator and province Orientale. Due to the differences observed in different sites, we suggest that this parameter should be more refined for each production site, as to better appreciate the reconstitution rate in each production forest.

\section{Conclusion}

This study aimed to analyse the response of Pericopsis elata to a delay thinning, conducted in abandoned plantations settled in 1973-1975 in the South and East regions of Cameroon. Because of the big delay observed (34-37 years), the tree crowns inter-cross, showing a high competition for light due to high tree density. Many trees were bump and winding. The annual diameter increments obtained in 2009 are low compared to results obtained in past years in the same plots, translating the negative effect of the absence of silvicultural treatment on mortality, competition between trees, and probably the normal growth rate which is a function of age. The first thinning done in 2009, improved the quality, the stand basal area and diameter increment of trees. The most important stand basal area, average diameters and average annual diameter increment are observed in the thinned plots. The second thinning occurred in May 2015, cutting 15\% of trees in each of the two previous plots. The next campaign of forest inventory should be scheduled by 2021, as to re-examine the effect of this treatment on the health and growth of Pericopsis elata trees. Results obtained in different studies conducted in range countries tend to show that the annual diameter increment varies not only with the age of plantation, but also with other parameters such as the site, the planting method, and probably the silvicultural treatment. This suggests that the annual diameter increment, which is an important parameter, used in the calculation of the reconstitution rate in forest management in the Congo Basin countries, should be measure and carefully refined for each production site.

\section{Acknowledgement}

The study was supported by the International Tropical Timber Organization (ITTO) and Convention on International Trade in Endangered Species of Fauna and Flora (CITES), within the so called "ITTO-CITES Program for Implementing CITES Listings of Tropical Tree Species". That program was primarily funded by the European Commission and executed in Cameroon by the National Forestry Development Agency (ANAFOR).

\section{Disclosure statement}

No potential conflict of interest was reported by the authors. 


\section{References}

Akoa, A., Betti, J. L., Bindzi, I., Bilong, P., Tchatat, M., Ndam, N., Onana, M., \& Assembé, S. (2009). Non-detriment findings report on Pericopsis elata (Fabaceae) in cameroon. Report prepared for the National Forestry Development Agency (ANAFOR), Cameroon's CITES Scientific Authority for flora. p. 97.

Anglaaere, L. C. N. (2005). Improving the sustainability of cocoa farms in Ghana through utilization of native forest trees in agroforestry systems. PhD Thesis: University of Wales, Bangor, UK.

Bourland, N. (2013). Dynamique d'une espèce ligneuse héliophile longévive dans un monde changeant : le cas de Pericopsis elata (Harms) Meeuwen (Fabaceae) au sud-est du Cameroun. Thèse de doctorat: Université de Liège - Gembloux Agro-Bio Tech, Gembloux, Belgique.

Bourland, N., Kouadio, Y. L., Lejeune, P., Sonke, B., Philippart, J., Daïnou, K., Fétéké, F., \& Doucet, J-L. (2012). Ecology of Pericopsis elata (Fabaceae), an Endangered Timber Species in Southeastern Cameroon. Biotropica, 44(6), 840-847. https://doi.org/10.1111/j.1744-7429.2012.00874.x

Boyemba, B. F. (2011). Ecologie de Pericopsis elata (Harms) Van Meeuwen (Fabaceae), arbre de forêt tropicale africaine à répartition agrégée. Thèse de doctorat : Université Libre de Bruxelles, Bruxelles, Belgique.

Breda, N., Granier, A., \& Aussenac, G. (1995). Effects of thinning on soil and tree water relations, transpiration and growth in an oak forest (Quercus petraea (Matt.) Liebl.). Tree Physiology, 15(5), 295-306.

https://doi.org/10.1093/treephys/15.5.295

CITES. (2003). Review of Significant Trade: Pericopsis elata, PC 14 Doc. 9.2.2.

Dickson, B., Mathew, P., Mickleburgh, S., Oldfield, S., Pouakouyou, D., \& Suter, J. (2005). An assessment of the conservation status, management and regulation of the trade in Pericopsis elata. Fauna \& Flora International, Cambridge, UK. p. 68.

Donis, C. (1956). La forêt dense congolaise et l'état actuel de sa sylviculture. Bull. Agric. Congo Belg., 47(2), 261-289.

Drapeau, C. (2005). Effet de l'éclaircie commerciale sur la structure et la composition végétale des peuplements naturels de pin gris. Mémoire de maîtrise en biologie, Université du Québec en Abitibi Témiscamingue. p. 132.

Engbwem, L. (1988). Comportement de l'Assamela dans la réserve forestière de Kienke'- Sud. Mémoire Ingénieur, Centre Universitaire de Dschang. Ecole Nationale Supérieur d'Agronomie. Dschang, Cameroun.

Etoga, G. E. M. (1991). Etude du prix de revient des ope'rations de transport de grumes dans une société d'exploitation forestière: cas de la SOFIBEL. Mémoire Ingénieur, Centre Universitaire de Dschang. INADER-Cameroun.

Food and Agriculture Organization (FAO). (2008). Fiche de renseignement sur les essences dont le patrimoine génétique s'appauvrit. Retrieved from http://www.fao. orgdocrep006k1203fK1203F11.htm (07/01/2010).

Grison, F. (1979). Les plantations d'Assamela (Pericopsis elata) en forêt semi-décidue Camerounaise. Centre de Recherches Forestières. Programme Centre et Est. Cameroun. 16 p + Annexe.

Guitet, S., Blanc, L., Trombe, P-J., \& Lehallier, B. (2009). Silvicultural treatments in tropical forest of Guiana. A review of ten years of trials. Bois et forêts des tropiques, 301(3), 7-19. https://doi.org/10.19182/bft2009.301.a20408

Howland, P. P. (1979). Pericopsis elata (Afrormosia). CFI Occasional Papers 9. Oxford, UK: University of Oxford.

ICCN. (2014). Non-detriment findings report on Afrormosia (Pericopsis elata) in the Democratic Republic of Congo. Congolese Institute for Nature Conservation (CITES Scientific Authority), ITTO-CITES program-EU/FAO. p. 63.

Jeong-Seok, K. M. S., \& Chang-Seob, S. (2014). The effect of forest-thinning works on tree growth and forest environment. Forest Science and Technology, 10(1), 33-39. https://doi.org/10.1080/21580103.2013.821958

Kemkeng, F. (2016). Réponse de Pericopsis elata (Harms) Van Meeuwen (Fabaceae) au traitement sylvicole, mémoire de DEA/Master II, Faculté des Sciences, Université de Douala, Cameroun.

Letouzey, R. (1985). Notice de la carte phytogéographique du Cameroun au 1/50 000. Institut de la carte internationale de la végétation. Toulouse-France et IRA de Yaoundé-Cameroun. p. 24. 
MINEF. (1995). National Forestry Action Programme of Cameroon. Ministry of Environment and Forestry, Forest policy document.Yaounde, Cameroon. p. 378.

MINFOF. (2016). State of the forestry sector in Cameroon. Ministry of Forestry and Wildlife, Yaoundé, Cameroon.

Moby, E. P., Morin, S., Muller, J., \& Gavaud, M. (1979). Atlas de la République Unie du Cameroun. Edition Jeune Afrique. Paris, France. p. 72.

Ngueguim, J. R. (2007). Dynamique de croissance et diversite floristique dans les peuplements forestiers plantés de Bidou et Mangombe. Mémoire de DEA, Universite' de Yaounde' I, Cameroun. 60 p + annexes.

Ngueguim, J. R., Betti, J. L., Riera, B., Ambara, J., Tchatat, M., \& Onana, J. (2012). Growth and productivity of Pericopsis elata (Harms) Meeuwen in some forest plantations of Cameroon. Forest Science and Technology, 8(1), 1-10. https://doi.org/10.1080/21580103.2012.658234

Nnanga, M. R. L., Gweth, L. R. S., Manga, E. F., Ekodeck, G. E., \& Din, N. (2019). Phenological Behavior of Pericopsis elata in a Production Forest at Libongo (Southeast Cameroon). International Journal of Sciences and Research Methodology (IJSRM), 12(1), 9-26.

N'zala, D., Loumeto, J., Kami, E., Yoka, J., Mombeki, S., Imbounou, A., Samba, J. L., Ossebi-Mbila, S., Banzouzi, J. C. (2011). Non-detriment findings report for Pericopsis elata in North Congo. International Tropical Timber Organization (ITTO) - Convention on International Trade in Endangered Species of Fauna and Flora (CITES) Program for Implementing CITES Listings of Tropical Tree Species. p. 86.

ONADEF. (1991). Inventaire d'aménagement de la forêt de Kienke'-sud. Ministère d'agriculture. Yaoundé, Cameroun.

République du Cameroun. (1994). Loi 94/01 du 20 janvier 1994 portant régime des forêts, de la faune et de la pêche. p. 57.

République du Cameroun. (1995). Décret n 95/531 du 23 août 1995 fixant les modalités d'application du régime des forêts. p. 66.

Schmitz, A. (1962). Établissement d'une courbe de répartition par âge d'une essence caducifoliée (Application à l'Afrormosia elata Harms). Bull. Soc. R. For. Belg., 12, 517-550.

Tchatat, M. (2009). Plan de gestion des plantations forestières de Pericopsis elata de Bidou (Kribi), Agence National d'Appui au Développement Forestier (ANAFOR)/Projet OIBT-CITES sur la mise en œuvre de la CITES. p. 48.

Vangu-Lutete, C. (1985). Rythme phénologique de l'Afrormosia elata Harms dans la région de Yangambi. Scientia, $1,31-43$.

Vivien, J., \& Faure, J. J. (1985). Trees of Central African forests. Ministry of foreign relations, cooperation and development -Cultural and Technical Cooperation Agency (ACCT), Paris. p. 551.

White, L. J. T. (1983). Vegetation study. Final report. Projet ECOFAC (Gabon). Groupement AGRECO.

\section{Copyrights}

Copyright for this article is retained by the author(s), with first publication rights granted to the journal.

This is an open-access article distributed under the terms and conditions of the Creative Commons Attribution license (http://creativecommons.org/licenses/by/4.0/). 